Nyquist, R. H. \& Bors, E. (I967). Mortality and survival in traumatic myelopathy during I9 years, from 1946 to 1965. Paraplegia, 5, 22-48.

Pearce, L. S. et al. (1964). Spinal cord injuries: Statistical review of 35 autopsies. Proceedings of Thirteenth V.A. Spinal Cord Conference, 88-93.

Pelot, M. G. (1963). Entero-cytoplasty in contracted bladder complicated by hydronephrosis. Paraplegia, I, 55-6I.

PenNisi, S. A. et al. (1959). Renal clearances in paraplegics with recent and old injuries. f. Urol. 82, $442-448$.

Powel, T. et al. (1967). Intravenous pyelography. A comparative trial of Io methods in patients with good renal function. Brit. F. Radiol. 40, 30-37.

PrICE, M. et al. (I966). Renal function in patients with spinal cord injuries. Arch. phys. Med. 47, 406-4II.

Ross, C. J. (1963). Surgical treatment of hydronephrosis in paraplegics. Paraplegia, $\mathbf{1}$, I37-I 48.

Schales, O. \& Schales, S. S. (I94I). Simple and accurate method for the determination of chloride in biological fluids. F. biol. Chem. 140, 879-884.

SMITH, J. F. (1962). Diagnosis of scars of chronic pyelonephritis. Clin. Path. 1 5, 522-526.

Sonnenwirth, A. C. (1963). In Gradwohl's Clinical Laboratory. Methods and Diagnosis. The C. V. Mosby Company.

TALBOT, H. S. (I966). Renal disease and hypertension in paraplegics and quadriplegics. Med. Ser. F. Can. 23, 570-575.

TALвот, H. S. et al. (1967). Uretero-vesical dynamics in relation to reflux. Paraplegia, 5, 97-IO3.

TobIAs, C. J. et al. (1962). Endogenous creatinine clearance. New Eng. F. Med. 266, 3I7-323.

Van Pilsum, J. F. \& Bovis, M. (I957). Effect of various protein precipitants on recoveries of creatinine added to plasma. Clin. Chem. 3, 90-94.

Whitesel, J. A. \& HelleR, E. (I964). Intensification of the excretory urogram by continuous infusion of contrast material. F. Urol. 92, 224-229.

\title{
CHEMOTHERAPY IN CHRONIC URINARY TRACT INFECTION
}

By Leon Bernstein-Ha HN, M.D.

Ministerio de Asistencia Social y Salud Pública Centro Nacional de Rehabilitación del Lisiado Buenos Aires, Argentina

THE management of the urinary tract infections is one of the main challenges for the urologist dealing with spinal cord injury patients. We use sulphonamides and other antibacterial substances sparingly, to control many severe infections that are seldom encountered in other Rehabilitation Centres. Like Bors, we believe that the developing of auto-immunity is one of the paths in this difficult task and forced diuresis may help in the control of even some acute pyelonephritis.

A new antibacterial combination was tested in the treatment of chronic urinary tract infections resistant to other drugs. A pyrimidine derivative, trimethoprim, that acts with sulphonamides in a sinergic and bactericidal manner, and sulfamethoxazole (Gantanol ${ }^{1}$ ); expecting a greater intensity of action, broader spectrum of activity, transforming a bacteriostatic into bacteriocidal effect and diminishing the development of resistance in a number of bacteria.

Chemically, trimethoprim is 2, 4-diamino-5 (3', 4', 5'-trimethoxybenzyl)pyrimide. Its molecular formula is $\mathrm{C}_{14} \mathrm{H}_{18} \mathrm{~N}_{4} \mathrm{O}_{3}$, and its molecular weight 290.3. Gantanol contains as active substance 5-methyl-3-sulfanilamido-isoxazole.

We used this combination in two dosages:

${ }^{1}$ F. Hoffmann-La Roche \& Co. Ltd., Basle, Switzerland. 
Ro 6-2580/41 (Gantanol $500 \mathrm{mg}$. + trimethoprim $50 \mathrm{mg}$ ) and

Ro 6-2580/9 and I I ${ }^{1}$ (Gantanol $400 \mathrm{mg}$. + trimethoprim $80 \mathrm{mg}$.).

\section{METHOD AND MATERIAL}

Ro 6-2580/4 combination was tested for five days in a series of $5 \mathrm{I}$ patients, out of which $3 \mathrm{I}$ had neurogenic bladders or G.U. obstructions, I4 carried stones and 20 were free of obstructions.

All of them had, prior to treatment, a bacterial count above 10,000 colonies and over 50,000 W.B.C. per ml. of mid-stream urine passed first thing in the morning.

TABLE I

Chronic Urinary Infections treated with RO 6-2580/4-Results

\begin{tabular}{|c|c|c|c|c|c|}
\hline & \multirow{2}{*}{ Urine Culture } & \multicolumn{2}{|c|}{5 th day } & \multicolumn{2}{|c|}{8 th day $\star$} \\
\hline & & No & $\%$ & No & $\%$ \\
\hline Negative & . $\quad . \quad$. & I2 & $23 \cdot 5$ & I 2 & $24 \cdot 5$ \\
\hline Positive & $\left\{\begin{array}{l}<5000 \text { colonies } \\
5000-10,000 \text { colonies } \\
>\text { I0,000 colonies } .\end{array}\right.$ & $\begin{array}{r}12 \\
3 \\
24\end{array}$ & $\begin{array}{r}23.5 \\
6 \cdot 0 \\
47 \cdot 0\end{array}$ & $\begin{array}{r}13 \\
4 \\
20\end{array}$ & $\begin{array}{r}26 \cdot 5 \\
8 \cdot 0 \\
4 \mathrm{I} \cdot 0\end{array}$ \\
\hline Total & . & $5 \mathrm{I}$ & $100 \cdot 0$ & 49 & $100 \cdot 0$ \\
\hline
\end{tabular}

$\star$ Two patients were not registered on the 8 th day.

The following tests were performed prior, at the end and at least three days after treatment: complete blood count, alkaline phosphatase, transaminase, bilirrubin, B.U.N., cholesterol and eritrosedimentation rate. In five hospitalised patients these tests were performed daily.

We arrived at the results shown in Tables I to IV.

Out of 24 patients who ended up with a colony count over $10^{4}$, I 2 were obstructed, including nine with lithiasis, I 5 of these patients were submitted then to antibiotics with very good results in three, good in three, fair in five and four failures although no one sterilised the urine culture.

In a second group, 32 patients with chronic urinary tract infections without known obstructions were placed on a regime of Ro 6-2580/9-I I (Gantanol $400 \mathrm{mg}$. +trimethoprim $80 \mathrm{mg}$.) one or two tablets twice a day for seven days with the same laboratory controls at the beginning, end and three days after the treatment. A colony count below I0,000 and diminishing white cell excretion was considered a sign of success. Thirty-one per cent. of patients were cured and 59 per cent. improved.

The urinary white cell excretion diminished below $100,000 \times \mathrm{ml}$. in 57 per cent. of the patients three days after treatment. The W.B.C./H.P.F. below five was found in 38 per cent. three days after treatment, as compared with $\mathrm{I}, 000,000$ W.B.C. $\times$ ml. and ro W.B.C./H.P.F. in 90 per cent. and 87 per cent. prior to it.

\footnotetext{
${ }^{1}$ F. Hoffmann-La Roche \& Co. Lth., Basle, Switzerland.
} 
Chronic Urinary Tract Infections treated with Ro 6-2580/4-Urinary White Cell Count

\begin{tabular}{|c|c|c|c|c|c|c|}
\hline \multirow[t]{2}{*}{ W.B.C. $\times$ ml. of Urine } & \multicolumn{2}{|c|}{$\begin{array}{c}\text { Before } \\
\text { treatment }\end{array}$} & \multicolumn{2}{|c|}{$\begin{array}{c}5 \text { th day } \\
\text { (end of } \\
\text { treatment) }\end{array}$} & \multicolumn{2}{|c|}{ 8th day* } \\
\hline & No & $\%$ & No & $\%$ & No & $\%$ \\
\hline $0-50,000$ & - & 一 & 25 & 49 & 23 & 47 \\
\hline $50,001-100,000$ & 5 & IO & 2 & 4 & 6 & 12 \\
\hline $100,001-200,000$ & 4 & 8 & 5 & IO & 6 & I 2 \\
\hline $200,001-300,000$ & 5 & IO & 3 & 6 & - & - \\
\hline $300,001-400,000$ & 2 & 4 & - & 一 & 3 & 6 \\
\hline $400,001-500,000$ & 3 & 6 & - & - & - & $\cdots-$ \\
\hline $500,001-600,000$ & 4 & 8 & 2 & 4 & 一 & - \\
\hline $600,001-700,000$ & I & 2 & - & $\cdots$ & $\mathbf{I}$ & 2 \\
\hline $700,001-800,000$ & I & 2 & 2 & 4 & I & 2 \\
\hline $800,001-900,000$ & 5 & IO & I & 2 & - & - \\
\hline $900,001-1,000,000$ & I & 2 & - & - & - & $\ldots$ \\
\hline I,000,00I-2,000,000 & 2 & 4 & 3 & 6 & 3 & 6 \\
\hline more than $2,000,000$ & I8 & 35 & 8 & I6 & 6 & I2 \\
\hline
\end{tabular}

$\star$ Two patients were not registered on the 8th day.

TABLE III

Urinary Tract Infections-Follow-up of the Bacterial Colonies Count

\begin{tabular}{|c|c|c|c|c|c|c|}
\hline \multirow[t]{2}{*}{ Colonies $\times$ ml. of Urine } & \multicolumn{2}{|c|}{$\begin{array}{l}\text { Before } \\
\text { treatment }\end{array}$} & \multicolumn{2}{|c|}{$\begin{array}{c}\text { 5th day } \\
\text { (end of } \\
\text { treatment) }\end{array}$} & \multicolumn{2}{|c|}{8 th day ${ }^{\star}$} \\
\hline & No & $\%$ & No & $\%$ & No & $\%$ \\
\hline $0-5000$ & - & - & 26 & 50 & 27 & 54 \\
\hline 500I-I0,000 & - & 一 & 2 & 4 & 4 & 8 \\
\hline $10,001-20,000$ & $\ldots$ & - & 5 & IO & I & 2 \\
\hline $20,001-30,000$ & I & 2 & 4 & 8 & 4 & 8 \\
\hline $30,001-40,000$ & - & - & - & 一 & 二 & -- \\
\hline $40,001-50,000$ & - & 一 & 2 & 4 & 3 & 6 \\
\hline $50,001-60,000$ & - & - & 5 & IO & - & $\ldots$ \\
\hline $60,001-70,000$ & 2 & 4 & 二 & 一 & 4 & 8 \\
\hline $70,001-80,000$ & 9 & 18 & - & $\ldots-.$. & 3 & 6 \\
\hline $80,001-90,000$ & 15 & 29 & 2 & 4 & I & 2 \\
\hline $90,001-100,000$ & 6 & 12 & 3 & 6 & 一 & -- \\
\hline $100,001-150,000$ & I3 & 25 & I & 2 & 2 & 4 \\
\hline I 50,00I-200,000 & 5 & IO & I & 2 & 一 & - \\
\hline
\end{tabular}

$\star$ Two patients were not registered on the 8 th day. 
TABLE IV

Urinary Tract Infections-Bacterial Findings

\begin{tabular}{|c|c|c|c|c|}
\hline \multirow{2}{*}{\multicolumn{2}{|c|}{ Bacteria }} & \multicolumn{3}{|c|}{ Number of frequencies } \\
\hline & & $\begin{array}{c}\text { Before } \\
\text { treatment }\end{array}$ & $\begin{array}{l}\text { 5th day } \\
\text { (end of treatment) }\end{array}$ & 8th day \\
\hline Escherichia coli & . & I4 & 4 & 6 \\
\hline Klebsiella & . & 9 & 7 & 2 \\
\hline Proteus vulgaris & . & 6 & 2 & 0 \\
\hline Pseudomonas aeruginosa & . & 5 & 5 & 6 \\
\hline Enterobacter cloacae & . & 5 & 3 & 3 \\
\hline Enterobacter aerogenes & . & 5 & - & 2 \\
\hline Proteus rettgerii & . & 3 & 2 & I \\
\hline Streptococcus faecalis & . & 2 & I & I \\
\hline Proteus mirabilis & & I & $\ldots$ & — \\
\hline Mixed infections (Strept. & er.) & I & - & $\ldots$ \\
\hline
\end{tabular}

TABLE V

Urinary Tract Infections-Follow-up of the Urinary White Cell Count

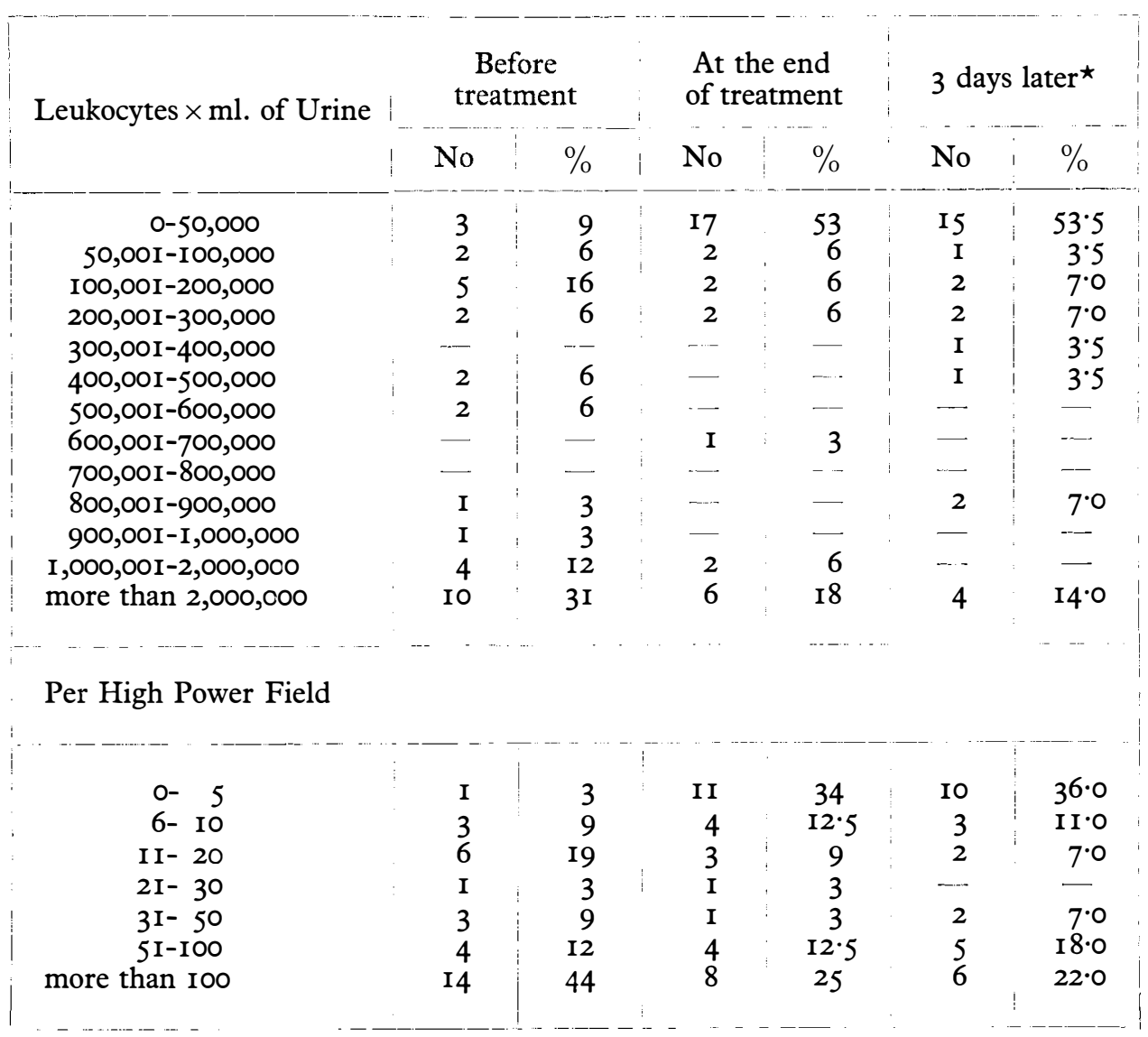

* Four patients did not follow up. 
TABLE VI

Chronic Urinary Tract Infections-Follow-up of the Bacterial Colonies Count

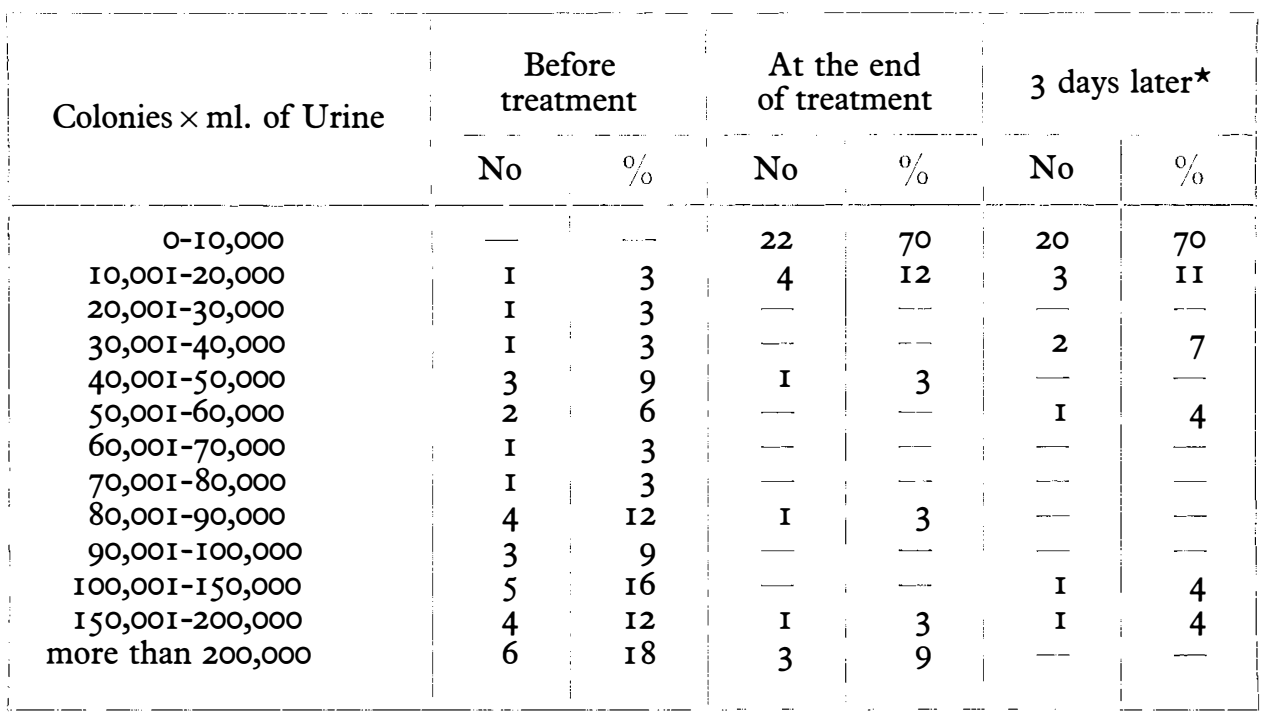

* Four patients did not follow up.

TABLE VII

Chronic Urinary Tract Infections-Bacterial Findings

\begin{tabular}{|c|c|c|c|c|c|c|}
\hline \multicolumn{4}{|c|}{ Bacteria } & \multirow{2}{*}{$\frac{\begin{array}{c}\text { Before } \\
\text { treatment }\end{array}}{13}$} & \multirow{2}{*}{$\begin{array}{c}\begin{array}{c}\text { At the end } \\
\text { of treatment }\end{array} \\
2\end{array}$} & \multirow{2}{*}{3 days later } \\
\hline Escherichia coli & . & . & . & & & \\
\hline Enterobacter sp. & . & . & . & 3 & I & I \\
\hline Klebsiella & . & . & . & 3 & - & - \\
\hline Proteus sp. & . & . & . & 2 & $\ldots \ldots-$ & - \\
\hline Proteus rettgerii & . & . & . & 3 & I & - \\
\hline Staphylococcus at & reus & . & . & I & - & $\ldots$ \\
\hline Aerobacter aeroge & nes. & . & . & I & - & - \\
\hline Streptocossus faec & alis & . & . & I & I & - \\
\hline Enterobacter cloa & ae . & . & . & I & I & - \\
\hline Proteus vulgaris & . & . & . & 2 & $\cdots$ & - \\
\hline Piocianic b. & . & . & . & I & 3 & 3 \\
\hline Citrobacter $\quad:$. & . & . & & I & - & - \\
\hline Proteus morganii & . . & . & & - & I & - \\
\hline Staphylococcus + & Enterob. sp & & & 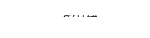 & - & I \\
\hline Proteus rettg. $+K$ & lebsiella . & & . & - & - & I \\
\hline Piocianic b. + Escl & er. coli & . & . & - & $\cdots-$ & I \\
\hline Total & . & & & 32 & IO & 7 \\
\hline
\end{tabular}

Germ change: eight cases. 
The bacterial count dropped below $10,000 \times \mathrm{ml}$. in $7 \mathrm{I}$ per cent. of patients.

Eight patients with fair results were placed on Gentamicin with six failures and two successes, three of these patients were later found to have unknown foreign bodies or lithiasis in the urinary tract.

The bacterial findings are shown in Table VII.

\section{SIDE EFFECTS}

We did not find any of importance. With Ro 6-2580/4 there was a drop in platelet count in three cases and with Ro 6-2580/9-I I in four, maintaining the normal values.

In one case there was an increase of glutamic-pyruvic-transaminase above normal levels, one developed a skin rash that lasted seven days and another one had gastric intolerance.

\section{SUMMARY AND CONCLUSIONS}

We report the clinical research of a new antibacterial combination (Gantanol+ trimethoprim; F. Hoffmann-La Roche \& Co. Ltd.) in the management of chronic urinary tract infections.

The combination Ro 6-2580/4 administered to $5 \mathrm{I}$ patients with and without G.U. obstructions ended up with 55 per cent. good results following. Kass criteria whereas the Ro 6-2580/9-I I in 32 patients without obstruction that rate increased up to the 75 per cent. of cases.

Few adverse reactions were noted.

\section{ACKNOWLEDGEMENTS}

We acknowledge the support of Productos Roche, Buenos Aires in this work, to Dr. Carlos A. Barclay, Dr. R. Birabén Losson, chemist and Dr. María Caria, bacteriologist.

\section{REFERENCES}

Csonka, B. W. \& Knight, G. J. (I967). Brit. F. Vener. Dis. 43, I6I.

Darrell, J. et al. (1968). F. Clin. Pathol. 21, 202.

Leading article (1968). Brit. Med. F. 2, 380.

Roth, B. et al. (I962). F. Med. Pharm. Chem. 5, i Io3.

SOURANDER, L. B. \& WerneR, G. (1967). Efficacy and tolerance of sulphonamide + trimethoprim combinations in geriatric patients with bacteriuria. Vth. Int. Congr. Chemoth., Vienna, June 26th.

\section{THE PATHOGENESIS OF RENAL INFECTION IN SPINAL CORD INJURY ${ }^{1}$}

By Herbert S. Talbot, M.D., F.A.C.S.

Spinal Cord Injury Service, Veterans Administration Hospital, West Roxbury, Massachusetts and Harward Medical School, U.S.A.

THE effect of the initial management of spinal cord injury patients upon subsequent changes in the upper urinary tract cannot be evaluated without an understanding of the pathogenesis of those changes. A day may be coming when infection will be avoided during treatment of the early stages of neurogenic bladder dysfunction,

1 Spinal Cord Injury Service, Veterans Administration Hospital, West Roxbury, Massachusetts and Harvard Medical School, U.S.A. 